\title{
THE LYONS AND IOWA CENTRAL RAILROAD.
}

BY RUTH IRISH PRESTON.

In 1836, seven years after the famous trial trip of the first American steam ear, on the Delaware and Hudson road, and while Iowa was yet a part of Wisconsin, the legislature of that territory at its first session, incorporated the "Belmont and Dubuque Railroad Company" and authorized it to construct a single or double track "from Belmont in Wisconsin to the most eligible point on the Mississippi river at or near Dubuque." This road was "to be operated by the power and force of steam, or animals, or any mechanieal or other power ;" and it was further provided that the company should not charge to exceed six cents per mile for carrying passengers, nor more than fifteen cents per ton per mile for transporting any species of property.

Although no road was built, the act is interesting as matter of history, for in it we find the first suggestion of a railway reaching Iowa.

On the 12th of June, 1838, President Van Buren approved an act dividing the Territory of Wisconsin and establishing the Territory of Iowa, which act went into effect on the $3 d$ day of July following. Immigration was rapidly tending this way now that Black Hawk had laid down his arms, for the fame of the beauty and richness of Iowa's rolling prairies had reached far eastward. So rapidly did the population of Iowa Territory increase that in 1846 she was admitted to statehood. No bands of iron or steel at this time bound her east and west borders together, or held her in touch with older settlements to the eastward. Her methods of transportation were of the most primitive. The stage-coach and steamboat represented rapid transit, and the faithful ox-team gave slow but sure service. Iowa's fertile prairies were even at this time yielding a superabundance of food stuffs; she had also rich mines of lead and eoal; but without an easier, cheaper and more rapid means of transportation these were valueless, ex- 


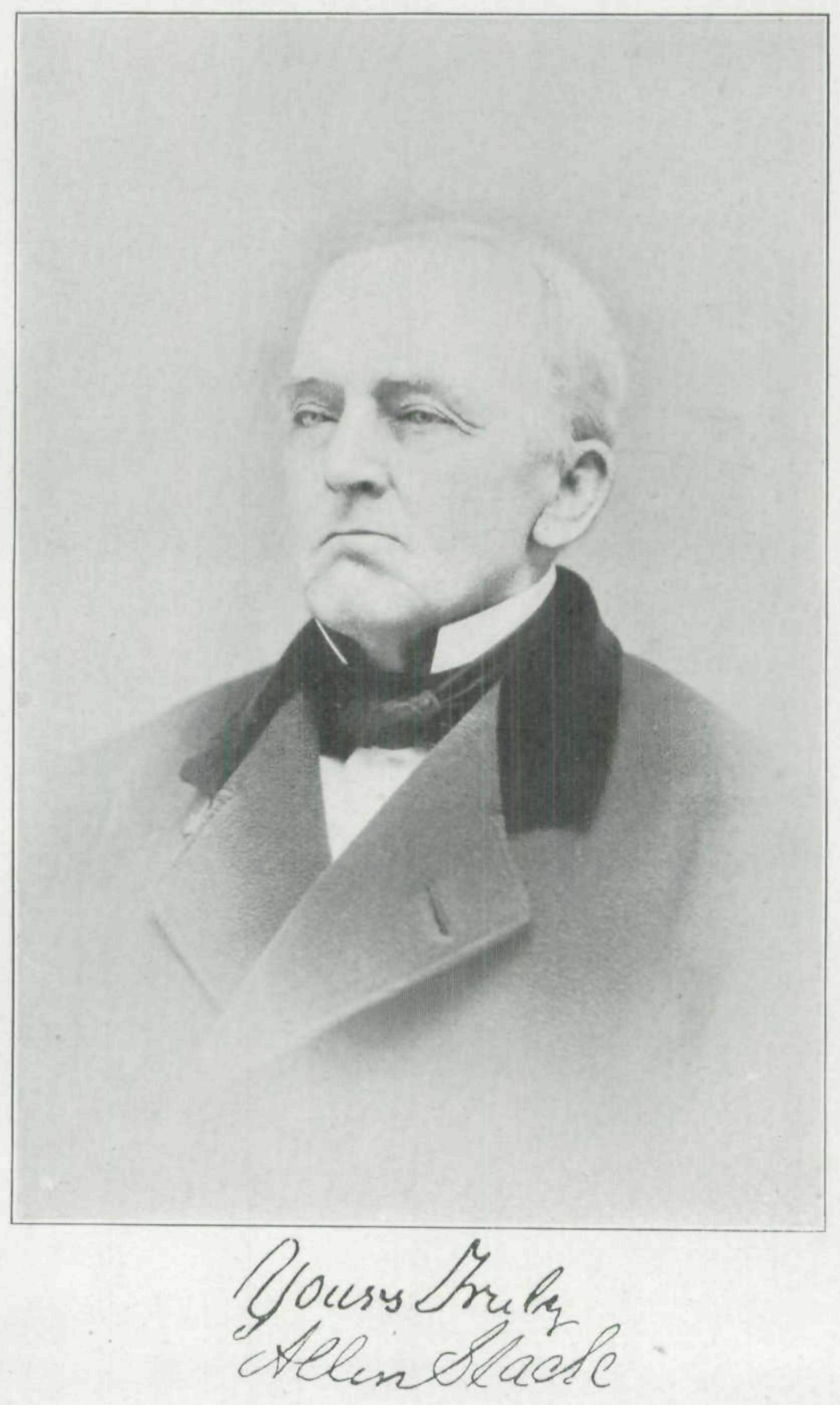


cept in so far as they were needed for home consumption. Railroads from the far east were now pushing themselves westward, ever westward, carrying to isolated settlements many of the comforts and luxuries of a more refined and less strenuous life. But as yet no line had reached the Mississippi. Still there was railroad talk and there were schemes; but no actual work was done until 1852 when two roads germinated-the "Lyons and Iowa Central," which put its men in the field locating, and the "Mississippi and Missouri" which organized, but did not begin operations that year.

Previous to this time all efforts had been toward the improvement of the inland waterways, but in this year, when the Fourth General Assembly convened at Iowa City (December 6, 1852) Governor Hempstead recommended that the Legislature "urge Congress to make a grant of public lands to aid in the construction of railroads in Iowa;" and at this session strong efforts were made to secure land grants to aid in the construction of several lines in the State. James W. Grimes, an influential member of the House from Des Moines county, was one of the most active in these efforts. A project to aid a line from Dubuque to Keokuk via Iowa City failed, but those friendly to east and west roads finally secured the passage of memorials for aid to three such trunk lines.

In 1850 a company had been organized in Iowa City to build a road from the Mississippi to that place. This organization was known as the "Iowa City and Davenport Railroad Company," and later, having taken no steps toward construction, other than the making of a preliminary survey, its franchise was transferred to the "Mississippi and Missouri" companyafter its organization in October, 1852,- on the condition that the road should be built through Iowa City. This transfer was made May 25, 1853. The "Chicago, Rock Island and Pacific" eventually secured this route, and in 1856 its road was completed to that point.

However, before the organization of the "Mississippi and Missouri" company in October, and before the recommendation of Governor Hempstead concerning land grants in December, 1852, the "Lyons Iowa Central" engineering corps 
was in the field, locating its line from Lyons westward. I quote the following from the journal of my father, C. W. Irish, who was a member of that engineering party: "October 15, 1852. Today I entered the corps of engineers at work setting grade stakes on the Lyons Iowa Central Railroad. The party eonsists of the following persons: Mr. J. I. Wanzer, assistant engineer; C. H. Holbrook, as rodman; J. Wright, as teamster; Wm. Hunter, and myself as axemen." During the next two months Mr. Irish, then a youth of eighteen, worked back and forth several times between Iowa City and Lyons, serving for a time as chainman in Mr. Buck's party and then as rodman in R. P. Mendenhall's corps.

In January, 1853, Mr. Estes and party arrived at Lyons, after which Mr. Allen Slack, chief engineer, made different arrangements for the several parties under his charge. The winter of 1852-53 was not a very pleasant camping season. My father records that, "The winter has been a remarkably cold one, the thermometer standing several times at 18 and 20 degrees below zero. The Mississippi river is frozen to a greater depth than it has been for some time and the ground is cracked open in every direction."

As further proof of the priority of the Lyons Iowa Central work over that of any other railroad in the State, I cite the following from a recent letter to me from Hon. Peter A. Dey of Iowa City:

In the spring of 1853 , while in charge of the construction of a division of the Chicago and Rock Island railroad in Bureau Valley, Illinois, I was instructed to make a survey of a railway from Davenport to Iowa City to be followed by a location as early as practicable. Before it was fully completed it was turned over to Mr. B. B. Brayton and I directed to make a survey to such point on the Missouri river as I deemed practicable for the starting of a line of railway to be extended up the Platte valley. My instructions in this regard were liberal. The haste to make this survey was occasioned by the fact that a line was being surveyed on practically the same route by the Lyons Iowa Central railroad company. This survey was being made by a Mr. Buek, a land surveyor living near Lyons. Having occasion to observe some of Mr. Buck's work I saw that his object was evidently to get as near as practicable an air line from one county seat to the next. This was usually followed 
by a vote in every county in favor of issuing bonds to aid in the construction of the railroad. Under this plan bonds were voted, and, as I remember, issued in Clinton, Cedar and Johnson counties, and voted but not issued in Iowa, Jasper, Poweshiek and Polk counties. The haste in making the Chicago and Rock Island surveys seems to have been to prevent if possible the further issue of bonds by any other counties until something was definitely determined. At that time it was thought by parties interested in the Rock Island road that money could be procured from the securities of the road to build across the State of Iowa as soon as the conditions warranted. When I came into the State there was a strong feeling, particularly in Cedar, Poweshiek, Jasper and Polk counties, in favor of the Lyons Iowa Central project, which was stimulated by a railway campaign that put its orators in the field. The head and brains of this project was H. P. Adams, a gentleman I believe from Syracuse, N. Y.

Looking further for information regarding this first railroad work in Iowa, I find in the "First Annual Report" of the Lyons Iowa Central, an article from the Chicago Democrat of Feb. 4, 1854, concerning the "Galena Air Line" (a road then under construetion by the "Galena and Chicago Union Railroad," " parent of the railroad system of Illinois") which was then completed to the village of Lane, in Ogle county, seventyfive miles west of Chicago. The article states:

The whole of the road is under contract and is to be completed to the Mississippi by the first of August next. At Dixon it crosses the main line of the Illinois Central and will furnish the people living on the line of that road, for many miles north and south of that point, direct railway communication with our city. At Fulton City it is said there is a fine point for crossing the Mississippi. The plan of the bridge places it one hundred feet above high water mark, and of course it would be no impediment to navigation. From Chicago to Fulton City the distance is 135 miles. There will be two daily passenger trains and one freight train leaving the city on the first of May next. The extension of the Galena Air Line westward is called the "Lyons, Iowa Central Railroad." Council Bluffs, on the Missouri, is the point to which several of the extensions of the roads from this city are aiming, and that is to be the western terminus of this road. It is under contract and the money is provided to build it to Iowa City, seventy-three miles. The distance from Lyons to Council Bluffs is 308 miles. It is to be completed to Tipton, fifty miles west of the Mississippi, by the first of October next. This part of the road is to be nearly an air line. Five hundred men are now at work upon the road. The country 
through which it passes is as fine as any portion of the Mississippi valley and it may therefore be expected to add very much to the business and general prosperity of the city. It is to be completed to Iowa City by the first of April, 1855 .

The "First Annual Report"' of the Lyons Iowa Central railroad company is a very interesting document. The directors' report to the stockholders states that, "On the 14th day of February, 1853, the company was organized in accordance with the provisions of the law of Railroads and the Right of Way in the State of Iowa." A copy of this law is appended to the report and is signed by George W. MeCleary, Secretary of State. The Report further tells us:

Subscriptions to the capital stock have been made as follows:

By individual subscribers.............\$686,300

By Cedar county, in bonds............ 50,000

By Johnson county, in bonds........... 50,000

By Jasper county, in bonds............ 42,000

By Polk county, in bonds............ 150,000

Total $\ldots \ldots \ldots \ldots \ldots \ldots \ldots \ldots \ldots \ldots \ldots \ldots \ldots \ldots, \overline{\$ 978,300}$

There have been prepared for issue, and a mortgage has been executed on the first division of the road for the security of the payment thereof, 800 bonds of $\$ 1,000$ each, $\$ 800,000$. The individual and county subscriptions being a basis for the issue to this amount.

Assurances are made, and may be relied on with confidence, that six additional counties will subscribe for stock and authorize an issue of their bonds to an aggregate amount of $\$ 500,000$, making the present immediately prospective resources amount to $\$ 2,278,300$.

There is little doubt that the resources already secured, and the progress already made in constructing the road, will induee large individual subscriptions, as further means may be required.

There have been issued to contractors on account of grading and bridging, in bonds of the company, $\$ 300,000$. The residue of the bonds prepared for issue are in the hands of the executive committee, to be issued for work on the First Division, as progress shall be made thereon. The amount of grading and bridging done, as will appear by the Chief Engineer's report, is about $\$ 200,000$. Materials for superstructure, rolling stock and iron have been purchased to the amount of $\$ 176,500$, making the expense for work done and materials purchased on the first division amount to $\$ 376,500$.

The work is now steadily progressing with a winter force of about 430 men and a corresponding number of teams and implements. As soon as the frost shall be out of the ground, to admit of a vigorous 
prosecution of the work, a sufficient force will be put on the line to bring that part of the first division as far west as Iowa City into running order as soon as possible.

The work of grading the second division, which extends westwardly to Fort Des Moines, will be commenced and prosecuted as rapidly as additional subscriptions to the stock of the company shall warrant.

The annexed reports of the chief and the consulting engineers are submitted as part of this report.

By order of the Board.

Wm. G. Haun, Vice-Pres.

Lyons, Iowa, Feb. 14, 1854.

The Board of Directors, chosen at the annual meeting, Feb. 14, 1854, were:

Thomas A. Walker, Fort Des Moines, Iowa.

James H. Gower, Iowa City, Iowa.

John Culbertson, Tipton, Iowa.

William G. Haun, Lyons, Iowa.

Derick Adams (N. Y.), Lyons, Iowa.

Hiram A. Tucker, Chicago, Ill.

Thomas Dyer, Chicago, Ill.

Paul B. Ring, Chicago, Ill.

David MeCartney, Fulton, Ill.

Thomas T. Davis, Syracuse, N. Y.

Henry P. Adams, Syracuse, N. Y.

Abel Chandler, New York.

S. M. Allen, Boston, Mass.

The officers appointed to manage the business of the company during the year were:

Thomas T. Davis, President.

Wm. G. Haun, Vice-President.

W. E. Caldwell, New York, Treasurer.

James McCoy, Secretary.

Allen Slack, Chief Engineer.

William C. Young, Consulting Engineer.

From the report of Chief Engineer Slack to the Board of Directors, February 14, 1854, I take the following excerpts, which show the progress of the work and the estimated cost of construction between Lyons and Tipton; and show also, how new a country Iowa then was, especially that portion lying west of Iowa City. Mr. Slack says: 
A survey was made early last spring and the fall previous, from Lyons to Iowa City, for the purpose of getting a general outline of the country.

On the third of May, 1853, I was directed to commence the location at the Mississippi river and to prepare it for grading. This was accordingly done, and the work commenced on the first 52 miles to Tipton.

From Tipton to Iowa City four lines have been run, and although a portion of the line next east of Iowa City has been located, and considerable work done, yet on account of the unevenness of the ground, I desire to make a more careful examination before submitting an estimate.

The survey west of Iowa City was commenced on the first of September, 1853, and in order to get through to Council Bluffs before cold weather there was no time to revise the line. This survey, however, I consider of great value, as furnishing data to indicate the final location. Portions of it, no doubt, will require little or no alteration, but as much will be susceptible of improvement, I considered it useless to prepare an estimate from the present notes, particularly as our services were so necessary elsewhere.

I would recommend that the whole line west of Iowa City be revised early in the spring, and that the country be more minutely explored on each side of the line, particularly on the north. . . . .

The State of Iowa is more rolling and more cut up by small streams than the State of Illinois, and the direction of your line is not the most favorable for the feasible construction of a cheap road; but from all the information I can obtain your route is more favorable than ean be found either north or south of it, and it is worthy of remark that at all the navigable streams which your line crosses, the grades are out of the reach of steamboat chimneys, while on either side of your route this would be impracticable. In addition to this advantage your route is peculiarly straight in direction from the Mississippi crossing to Council Bluffs. The grade of your road, as far as located, may be regarded as favorable for a maximum grade of 40 feet to the mile, there being no elevation at any one place exceeding 60 feet from the general level of the country.

As to directness, there is not one-eighth of a mile lost between Lyons and Iowa City, and for fifty miles east of Tipton there are only ten degrees of curvature, so that this part of your road can be safely run at a high rate of speed.

The total amount of excavation and embankment between Lyons and Tipton is 2,994,404 cubic yards. The paying amount is $1,723,688$ cubic yards which are estimated to cost $\$ 356,216.10$. The culverts and bridges are estimated to cost $\$ 34,283.90$, making the cost of grading $\$ 390,500.00$. 
After apportioning this total among the fifty sections of the division, Mr. Slack adds to it ten per cent. each for eontingencies and engineering, and arrives at an estimated cost of grading per mile between Lyons and Tipton of $\$ 9,372.00$. For the 24 miles from Tipton to Iowa City he estimates the cost of grading, eulverts, bridges, engineering and contingencies at $\$ 360,000.00$ or $\$ 15,000.00$ per mile, making a total from Lyons to Iowa City of $\$ 826,600.00$, or an average of $\$ 11,197.29$ per mile.

The country lying west of Iowa City is less favorable for the construction of your road than that on the east side, although no portion of Illinois or Iowa is better adapted to agricultural purposes than the section through which your line passes. In addition to the agricultural resources of this part of Central Iowa, capable of furnishing an immense freighting business, may be mentioned the extensive coal fields.

In view of the directness of the line through Central Iowa, and the advantages it possesses in regard to the several bridge crossings, I think there can be no doubt it will do the greatest share of through business, both in the conveyance of passengers and freight. In addition to the freight of Central Iowa that will seek an eastern destination, is the immense lumber trade from the Mississippi to supply the demand of Central and Western Iowa, which range of country, as well as the vicinity of Council Bluffs, is dependent on the Mississippi river for its supplies of pine lumber. This article alone will furnish a large western business.

No drawbridges will be necessary on the entire extent of your line.

Wm. C. Young, consulting engineer, in his report presented at the same meeting, concludes that "a capital outlay of $\$ 30,000$ per mile will suffice to construct and equip" the road. Of the proposed bridge over the Mississippi he says:

The expedient of a drawbridge, suitably elevated above the floods, may be adopted at Lyons as advantageously as at any other crossing of this great river, but in view of the preceding objections (obstruction to navigation and possible litigation resulting) and also the unavoidable delay and break of continuity in the line, and consequent danger to the trains, it may not be advisable to adopt such a plan of structure although less expensive than the other. A truss framed and arched superstructure of wood and iron combined, elevated 90 feet above high water, resting on piers 200 or 250 feet apart, would offer every attainable advantage for the purposes of your road. 
Another and a possible alternative may be found in the adoption of a suspension bridge of iron wire, at a sufficient elevation to avoid any obstruction to vessels. Suspension bridges for railroad purposes, although in process of construction in this country, may still be considered in a great degree as experimental. At Niagara Falls this kind of bridge is the only admissible mode of structure, and the one now being erected there will be fully tested during the present year.

\section{Of the Lyons bridge he says:}

Two sections of 1,000 feet each over the waterway, and one section of 500 feet over the depression of the receding banks on each side, or six sections of 500 feet each, will span the entire valley at the grade line. One pier or even three within the waterway, will leave the openings so large as to offer no appreciable obstruction to the navigation of the river.

The site of the proposed bridge over the Mississippi is peculiarly favorable. The rocky bluffs on the banks of the river, exceeding 100 feet in height, bold and precipitous on the east side, and more sloping on the west, approach each other more closely at this point than at any other locality available for a railroad crossing. . . .

There will be sufficient time for all practical purposes to decide upon the particular plan of bridge after some degree of experience is gained from the actual use of the suspension principle at Niagara Falls, as applicable to railroad purposes. The operation of a draw bridge and the effect of piers will also be exemplified in the case of the proposed bridge over the Mississippi at Rock Island.

It is now more than fifty years since the submission of the above report. During this time the two bridges mentionedthe Draw at Rock Island and the Suspension at Niagara-have given daily evidence of their "feasibility" and their "practicability," and yet the site for a bridge at Lyons, which the chief engineers of the Mississippi and Rock river road, also those of the Galena, Chicago and Union, united with those of the Lyons Iowa Central in pronouncing a favorable point for crossing, remains unoceupied.

Returning to Mr. Irish's journal for further information regarding the locating of the line, I read under the date of April 1, 1854:

I today commenced work in Mr. Allen Slack's corps, second division of civil engineers, as flagman. Heretofore I had served in the capacity of axe man. I have received my pay up to this date. The 
personnel of the party at this time is as follows: Mr. Estes, Asst. Engineer; W. W. Peck, 2d Asst. Engineer; J. W. Olds, G. Wilder, J. E. Ennis, Mr. Byers, J. Winters, R. P. Mendenhall, J. D. McCall, J. Hagarty, Wm. Hunter, R. M. Brandenberg and myself.

April 11. Made ready this morning for a start in Mr. Estes' company to run a line from Iowa City west to Fort Des Moines. The morning was pleasant. We started out from camp and ran a curve commencing at 3941 west of Iowa river.

The records of the days that follow are records of work and of storm, of pleasure and of weariness, of bridging swollen streams, getting swamped teams ashore, and of the men appeasing their appetites with "fat pork and corn dodger for supper, and corn dodger with fat pork for breakfast,' sometimes followed by a long day's work without water.

Hard as this railroad work seems to have been, there were yet many pleasant features about it, especially to those who easily made friends among strangers, and who had a love for Nature in her wildness. April 23d he records :

We retired last night with a clear sky over our heads, and the stars shining ever so brightly. We were soothed to repose by the tree toads' melancholy wail and the pheasants' kettledrum accompaniment. We slept and snored away until about four A. M., when we were rudely awakened by the bass notes of bellowing thunder. The wind began to blow hard, causing our tent to creak, snap and groan. We rousted out to secure it, the rain meanwhile pouring down upon us in torrents. By sunrise the clouds had cleared out of sight and the day became very warm. From the number of snakes killed near our tent we have named the place Snaky Hollow, and the grove-in compliment to the Pennsylvanians-Juniata grove.

The line as located by Mr. Estes" party started westward from Iowa City, passed about six miles south of Marengo, Iowa eounty, thence west to Sugar Grove, on the line of Poweshiek and Jasper counties, where were found, as the journal states, "the purest of spring water, plenty of grass for our beds and our horses, and enjoyable shade from the trees." This grove on the head waters of Sugar Creek, was reached early in May and here Camp No. 11 was made, of which Mr. Irish says :

The first night therein was hideous because of the howling of a pack of hungry, gray timber wolves which were stationed not far 
from our tents and kept up their concert and depredations most of the night. They were daring and ferocious. To satisfy their appetites they killed and ate one of our saddle horses. One of the boys, new to camp life and unacquainted with the diet preferred by wolves, suggested during the night that we had better bring in the potatoes which were left outside, as the wolves might eat them. Ha, ha! He will get his eyes opened!

May 15. Crossed the North fork of the Skunk river and are now entering in the midst of a Congregationalist colony. They have a large tract of land entered here. After the tragic death of our horse we have been careful to guard our animals day and night, and have reduced the number of wolves somewhat by the use of strychnine, which we obtained from some trappers. We have seen occasional deer and elk in this region.

May 21, Sunday. Bright and clear. While at breakfast we were surprised by a visit from a well-dressed gentleman who, after enquiring our business and destination, told us that he was a Congregationalist minister, that his name was Grinnell, and that but a few days before he, with a colony of people from New England and New York, had landed upon the heads of Sugar Creek to found a settlement in Poweshiek county. He took deep interest in our work and the advancement of the country, but because it was Sunday did not care to talk much of business. He invited us to come and hear him preach at two o'clock this afternoon, and pointing out the top of a large oak tree said the services would be held under that tree. We went at the appointed hour and heard for the first time in our experience, divine services resounding through the grove and awakening its echoes.

May 22. Today passed Mr. Grinnell's quaint log cabin nestled among the trees upon a little knoll. Have made a sketch of it.

This cabin, which is pictured in the Iowa Historical Record, October, 1896, was the embryo of the present college town of Grinnell.

While the Estes locating party were approaching Fort Des Moines those working east of Iowa City were racing with the Rock Island, which was doing effective work between Davenport and Iowa City, on what had been known as the Mississippi and Missouri route, and a great spirit of rivalry existed between the Rock Island men and those of the Lyons party. When the Lyons boys in their rush used any sort of material at hand for stakes, the Rock Island boys taunted and jeered and called attention to the fine oak stakes they were using. The Lyons boys retorted, "Of course the Rock Island should 
use something permanent, for it would be years before its track was laid if ever."

With jibes and jokes the opposing companies kept the attention and interest of the eitizens, who were ready to applaud whichever won the race.

Thus, with varied and interesting experiences, during the years ' 52 , ' 53 and ' 54 the Lyons Iowa Central was located to Des Moines; but was destined never to measure its length with iron rails, nor span the navigable streams with bridges "out of the reach of steamboat chimneys!"

That he who laughs last laughs best was fully exemplified in this contest, for the Lyons Iowa Central boys, in June, 1854, were all laid off indefinitely, many of them without recompense for their months of weary toil. What caused this sudden collapse of a project that seemed so flourishing, and was so well boosted financially by the communities through which the road was projected, was not quite understood then by the men in the field, and after a lapse of 55 years, cannot be fully determined now. The little evidence obtainable points to misappropriation of funds by some trusted party or parties, near the head of the company. Mr. Dey, in his interesting letter on the subject, says that one of the board of directors for the road, "H. P. Adams, of Syracuse, N. Y., was a fugitive from justice at the time that he was making his strong eampaign through the counties of Iowa, encouraging the issue of railroad bonds," in proof of which he tells the following story :

General Ney, a member of Congress from the Syracuse district, came to Chicago, called at the Rock Island office and while there stated he was in the West for a requisition to arrest Mr. Adams and take him back for trial in New York. This Mr. Adams was the one who had, as I have before stated, the machinery at work for obtaining for his road county bonds which pliant County Judges-as the plan was popular-readily issued. Judge Lee issued the Johnson county bonds, although it was stated that he had pledged himself not to do so.

It was generally believed, after the failure of Adams and his railway project, that with the county bonds he had made his peace with General Ney. At all events this gentleman entered heartily into the railway campaign in Adams' behalf, and being a popular orator, 
his services were very effective. I recall reading one of his reported speeches wherein he was advocating the advantages of a high bridge over the Mississippi river, a suspension bridge of nearly a mile span, where he used the following figure of speech: "The trains will cross the Father of Waters without detriment to the navigation of that noble stream. There will be no piers or other obstructions. Its abutments will be on the high hills. The good fellowship of the river and the railway will be shown as the locomotive laughs when the steamboat puffs in its face." As an orator at Tipton, on another occasion, his eloquence not exhausted, he uttered the following tribute to the man whom he had come into the West to arrest: "Caesar crossed the Rubicon to crush the liberty of Rome, H. P. Adams crossed the Mississippi to make the prairies blossom as the rose." It was said that General Ney went home happy and his clients were satisfied.

Following his reminiscence regarding Adams, Mr. Dey again says:

I think it was in June, 1854, that Mr. Adams, having used all of his resources, withdrew his men from the field, many of his contractors unpaid and his popularity gone. It is possible that Mr. Adams hoped, by getting bonds from all the counties between Lyons and the Missouri river, that he could form a basis that would enlist enough capital to build the road; if so his plans were certainly sanguine. It was generally believed, after his failure to accomplish anything, that it was a cold-blooded scheme to rob the counties and, after getting their bonds, pocket the proceeds and decamp.

When the collapse came it was a severe stroke, not only to the locating engineers but to the construction men as well. Between Lyons and Iowa City much if not all the road-bed had been completed. This grading work had been done by a large gang of Irish immigrants who had been brought from New York and Canada for the purpose. These men, with their families, some 2,000 persons in all, were now stranded at Lyons and vicinity, practically helpless and enduring great hardships. The railway company had supply stores at Lyons from which were issued to the graders - in lieu of their wages - groceries, dry goods and miscellaneous articles; but these supplies were exhausted long before the indebtedness was cancelled. It was from these stores that the enterprise was derísively called, and is still known as, "The Calico Road."

Returning to the bond issue which a number of the counties 
had made in favor of the Lyons road, and which produced litigation of long standing and intense interest, $\mathrm{Mr}$. Dey tells us : "Later I met in Chicago, Paul B. Ring, who was in some way connected with the project (he was one of the Board of Directors) who offered the Johnson county bonds - the $\$ 50,000$ that had been issued-for $\$ 35,000$. These bonds the county afterward paid in full with ten per cent. interest from date of issue." The counties had resisted the payment of these bonds, and were sustained by the Supreme Court of the State; but an appeal being taken to the United States Supreme Court, it was held that although the law authorizing their issue might be questionable, the counties having sold them, and having received in pay thereof the consideration named in the bonds, could not be released from the obligation voluntarily incurred.

The final climax of the bond issue is told as follows by Mr. Gilbert Irish in his "History of Johnson County":

After years of discussion and litigation a convention of counties was called December 15, 1868. Delegates from Washington, Muscatine, Johnson, Jefferson, Lee, Cedar and Poweshiek counties met in the eity of Muscatine. After a lengthy discussion the following preamble was adopted:

Whereas, the recent decision of the Federal court, involving corporation railroad bonds in this State seems to us subversive of our authority and the dignity of our State courts, and dangerous to the rights and privileges of citizens of the State, if not a positive and unwonted encroachment upon the jurisdiction of the State courts, therefore, Resolved, that this convention recommends to the citizens of the several counties, and citizens interested in this railroad bond question, to pay all their taxes except the rallroad tax, and refuse to pay that until all legal and practical remedies are exhausted.

Several other default resolutions were adopted, speeches were made by Hon. Rush Clark of Jahnson county, Charles Negus of Jefferson, Robert Gower of Cedar and by ex-Governor Kirkwood, who said: "All will admit that we have a right to make our state constitution and laws just as we please, provided we dc not trench upon the constitution of the United States. What value is this right if our courts cannot interpret the meaning of our constitution and laws."

Still, like Banquo's ghost, the railway bonds would not down, and in the following May, 1869, a United States Marshal 
eame to Iowa City and arrested the Board of Supervisors and City Council on a warrant for contempt, and took them as prisoners to Des Moines. When the United States entered the field it soon elosed the bond war. The terms of peace were brief and dictated by the victorious bond holders,-it was tax or prison, and tax it was for some years. And when the bonds were at last paid and the personal feeling had died out, it was discovered that meanwhile railroad building had gone rapidly on; so there was rejoicing, and general good feeling was restored. Also a permanent good had resulted, since in the Constitution of 1857, the people of Iowa, warned by this unhappy bond war, fixed the limit of indebtedness-State, county and eity-at 5 per cent. of the taxable valuation. On the failure of the Lyons company all its property was sold at sheriff's sale, and so ended this ill-starred venture which, with transit and level, followed by pick and spade, did the first actual railroad work in the State.

On Oetober 15, 1908, as it chanced just 56 years from the day on which my father began work for the Lyons road, I took my first trip over a part of its route. It was glorious October weather and the day, in every particular, was satisfactory for a pleasure excursion and conducive to a reminiscent mood. Accompanying me were the late Dr. P. J. Farnsworth, a pioneer resident of Clinton, who acted as guide, Mr. A. F. Ewers of Davenport, as photographer, and my son Charles.

We climbed first to the top of "Lone Grave Bluff," the highest and most abrupt point on the Misisssippi at Lyons overlooking what is known as the "Narrows,"' and upon which the western end of the proposed suspension bridge was to have rested. After enjoying the magnificent outlook for a time, and securing views of this point, and of Fulton Bluff opposite, on which was to have rested the eastern end of the bridge, we started westward from the top of Lone Grave Bluff. We journeyed along at grade, through eut and across fill until we reached the "Big Cut" some three miles from the river, in the ravine beyond which, in 1854, a large culvert was built of handsome cream-eolored stone, but of which culvert now not a stone remains. Built strong and true, it waited 


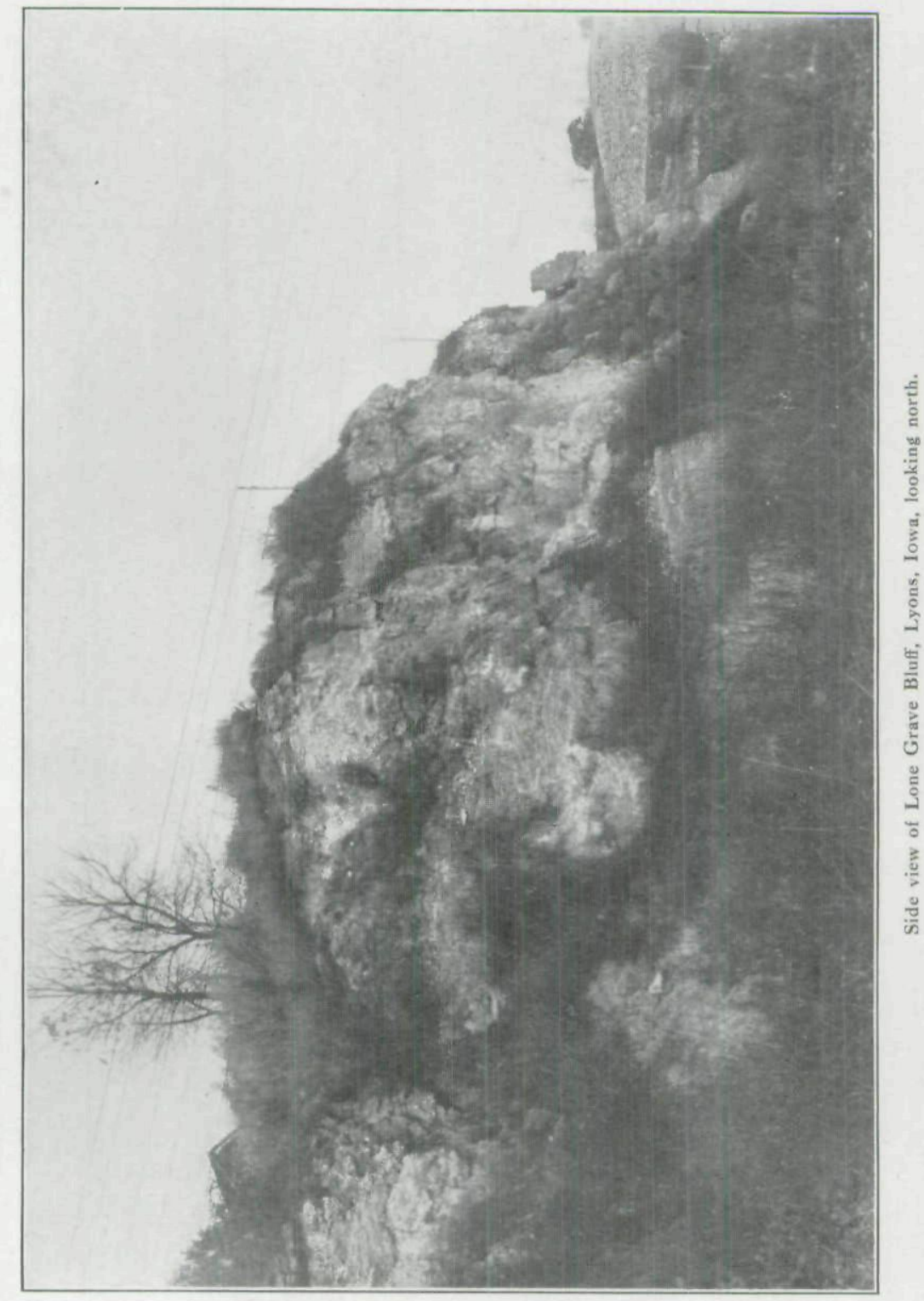


vainly through the years to feel the weight of commerce upon its strong back, and might still be waiting and wasting in vain had not the citizens of Lyons, after the failure of the road, shifted their interest and zeal from commercial to religious matters. Under the leadership of an Episcopal elergyman, Mr. Beers, who eame among them from the East about 1857, a goodly congregation was formed, and soon there was need for a church building. The panic of 1857 made funds scarce, but that did not deter the faithful. Material was at hand in the abandoned eulvert, and energetic hands soon had it metamorphosed from a burden bearer into a temple wherein men should learn to obey the command: "Bear ye one another's burdens." This was the first church erected in Lyons. It is still in use and in good repair. We took a photograph of the culvert site, and on our way home secured a good pieture of the church.

Stretching westward from Lyons the old road-bed, we were told, ean still be traced for forty miles or more; but our appetites being keen and our feet tired, we closed our tour of inspection at the historic culvert.

Later I visited points on the road-bed that are still visible at Iowa City, prominent among which are a big eut just outside and north of the Catholie cemetery, and a remnant of embankment at the head of Dubuque street which was to have formed the approach to the proposed bridge over the Iowa river. Soon these historic evidenees of the Lyons road will be gone, as are the men who wrought and suffered loss and disappointment in its work. As the laborer is worthy of his reward it is gratifying to realize that not a few of the men who bravely met defeat in this venture afterward attained distinction in their chosen profession. Prominent among these were Messrs. J. I. Wanzer, J. L. Estes, Allen Slack and Charles W. Irish. Of the after history of the two former I have as yet been unable to get definite data.

Mr. Slack, the Chief Engineer, was a native of Vermont, and a graduate of the University of that State, where he took a course in civil engineering. After graduation he went to New York, where he was employed on the Erie Canal until 
called west to take a position on the Illinois Central. Later he was sent into Iowa as Chief Engineer to locate the Lyons Iowa Central, making his home at Lyons. In 1880 he accepted a call to the Southern Pacific. Here he labored with eminent success until failing health foreed him to retire to his Oakland home, where he died in 1888 . To Mr. Slack's early work in Iowa, Hon. Peter A. Dey pays this tribute: "He succeeded Mr. Buck and made locations that were ereditable, and were adopted west of Iowa City in some places by the Rock Island company when their road was built."

Mr. Irish, although sharing defeat with the Lyons Iowa Central in its race with the Rock Island to Iowa City, had the pleasure a few years later, as locating engineer for the Northwestern, of helping to win the race to the Missouri river, which gained for this road the earrying of the U. S. mails, and of all the materials to be used in the construction of the Union Pacific; and resulted also in securing for the Northwestern the Congressional land grant of 1856 which had first been voted by the legislature to the Lyons Iowa Central.

Born in the Empire State in 1834, Mr. Irish was reared and educated in Iowa, to whose development he contributed not a little both as scientist and eivil engineer. After many years of suceessful railroad building throughout the great West he was appointed by President Cleveland, Surveyor General of the State of Nevada, and afterward was made Chief of the Bureau of Irrigation, which neeessitated his removal to Washington, D. C. Returning later to his home in Nevada he resumed his engineering work there, and died at Hope Gulch, Elko county in 1904.

In arranging his effects for removal to Nevada, he gave me, among other papers, his Lyons Iowa Central note book, on the last page of which stands recorded: "To 104 days work as second assistant Engineer for L. I. C. Ry., at $\$ 2.00$ per day, $\$ 208.00$, by loan to the President of the Co. $\$ 52.00$, sum total of indebtedness to C. W. Irish, $\$ 260.00$, which I never expect to get." And he never did.

For"the data collected in this paper I am indebted chiefly to my father's notes and the published report of the pro- 
jected road; also to Mrs. Ella Slack MeIntyre of Oakland, Cal., to the late Dr. P. J. Farnsworth, of Clinton, Iowa, Hon. Peter A. Dey of Iowa City, ex-governor Gue's History of Iowa, and the History of Johnson County by Hon. G. R. Irish. I wish also to acknowledge my indebtedness to Prof. A. F. Ewers of Davenport and Miss Jane T. Irish of Iowa City for photographs of interesting points on the old road bed.

\section{THE OLD-TIME TRAPPER.}

\section{Tacitus Hussey.}

The creeping on of eivilization during the last seventy years has wrought many marvelous changes. The man with the buckskin suit, the long rifle, the double-barreled shot gun, with the sheath knife and the hand axe dangling at his belt, silent during his busy hours, except when spoken to; yet garrulous enough over an evening pipe lighted at the camp-fire, has passed away from the Middle West. If he exists at all, it is in the land of the setting sun, or on the borders of the frozen lakes of the almost limitless Northwest.

It was from the lips of an old trapper, Landon Hamiltonwho seemed like an unbended bow, relaxed from its strainthat I gained my information for this article, including the modes of trapping game in the months containing the " $R$ 's" now usually associated with the "oyster season."

Iowa was originally part of the territory which formed a grand hunting and trapping ground for the Red Man, with his primitive weapons and traps, and later, for the pale face with the more modern weapons with which to kill and capture without thought of the morrow, all food and fur-bearing animals coming within range of the deadly rifle and the lure of the concealed steel trap.

The fur and food animals, in those early days, were the deer, wild turkey, pheasant, squirrel, wild goose, brant, duck, otter, beaver, wolf, mink, muskrat, raccoon, with an occasional black bear. Trappers usually had from forty to fifty steel 
Copyright of Annals of Iowa is the property of State of Iowa, by \& through the State Historical Society of Iowa and its content may not be copied or emailed to multiple sites or posted to a listserv without the copyright holder's express written permission. However, users may print, download, or email articles for individual use. 